Jurnal Konstruksi Hukum | ISSN: XXXX | E-ISSN: XXXX Vol. 1, No. 2, Oktober 2020, Hal. 305-309| Available online at https://www.ejournal.warmadewa.ac.id/index.php/jukonhum

DOI: https://doi.org/10.22225/jkh.1.2.2565.305-309

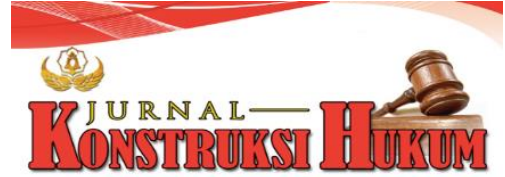

\title{
GUGATAN TIDAK DAPAT DITERIMA (NIET ONTVANKELIJKE VERKLAARD) DALAM GUGATAN CERAI GUGAT DI PENGADILAN AGAMA BADUNG
}

\author{
I Gusti Agung Ketut Bagus Wira Adi Putra, Ida Ayu Putu Widiati, Ni Made Puspasutari \\ Ujianti \\ Fakultas Hukum Universitas Warmadewa, Denpasar-Bali, Indonesia
}

\begin{abstract}
Abstrak
Dalam perjalanan rumah tangga selalu terdapat perselisihan antar pasangan suami-isteri yang tak dapat diselesaikan dan berujung pada perceraian. Penelitian ini bertujuan untuk mengetahui akibat hukum terhadap gugatan tidak dapat diterima dalam perkara cerai gugat pada putusan nomor 0063/Pdt.G/2017/PA.Bdg dan mengetahui pertimbangan hakim dalam memutus gugatan tidak dapat diterima dalam perkara gugatan cerai gugat pada putusan nomor 0063/Pdt.G/2017/PA.Bdg. Penelitian ini menggunakan metode penelitian hukum normatif dengan pendekatan kasus. Hasil penelitian menunjukan bahwa dalam Undang-Undang Nomor 1 Tahun 1974 tentang perkawinan dalam Pasal 39 ayat (2) Undang-Undang Perkawinan serta penjelasannya menyatakan bahwa perceraian dapat dilakukan apabila sesuai dengan alasan-alasan yang telah ditentukan. Putusan tidak dapat diterima $(N O)$ adalah putusan yang menyatakan gugatan tidak dapat diterima, karena cacat formil. Kemudian, alasan yang menyebabkan gugatan tidak dapat diterima karena cacat formil yaitu surat kuasa tidak sah, gugatan diajukan oleh pihak yang tidak berkepentingan hukum, gugatan eror in persona, gugatan diluar kompetensi, gugatan osbcuur libel, gugatan prematur dan gugatan daluwarsa. Gugatan Obscuur Libel adalah gugatan yang kabur atau tidak jelas dan penyebab gugatan obscuur libel dalam perkara ini adalah petitum tidak rinci oleh karena itu gugatan tidak dapat diterima.
\end{abstract}

Kata Kunci: Gugatan Tidak Dapat Diterima; Putusan; Cerai

\begin{abstract}
In the course of the household, there are always disputes between husband and wife that cannot be resolved and lead to divorce. This study aims to determine the legal consequences of an unacceptable lawsuit in a lawsuit divorce case in decision number 0063 / Pdt.G / 2017 / PA.Bdg and to find out that the judge's consideration in deciding a lawsuit cannot be accepted in a divorce suit in decision number 0063 / Pdt.G / 2017 / PA.Bdg. This study uses a normative legal research method with a case approach. The results of the study show that in Law Number 1 of 1974 concerning marriage in Article 39 paragraph (2) of the Marriage Law and its explanation it states that divorce can be carried out if it is in accordance with predetermined reasons. An unacceptable decision (NO) is a decision stating that a lawsuit cannot be accepted, because of formal defects. Then, the reasons that cause the lawsuit to be unacceptable due to formal defects are invalid power of attorney, lawsuit filed by parties who have no legal interest, in person error suit, lawsuit beyond competence, lawsuit against libel, premature lawsuit and lawsuit expired. Libel's lawsuit is vague or unclear and the cause of obscuur libel's lawsuit in this case is an incomplete petitum, therefore the lawsuit cannot be accepted.
\end{abstract}

Keywords: Unacceptable Lawsuit; Verdict; Divorce

\section{PENDAHULUAN}

Manusia secara kodrat ialah mahluk sosial yang artinya tidak dapat hidup sendiri tanpa bantuan dari orang lain. Selain itu, manusia pada dasarnya diciptakan untuk hidup berpasangan. Jadi, tidak mengherankan lagi jika manusia memiliki hasrat untuk menikah. Pernikahan atau perkawinan merupakan hal yang sangat penting dalam kehidupan setiap umat manusia, seperti yang tercantum dalam Pasal 1 Ayat (3) Undang-Undang Negara Republik Indonesia Tahun 1945 di tegaskan tentang Konsep Negara Hukum, Indonesia merupakan negara hukum yang didalamnya terdapat UndangUndang yang mengatur mengenai Perkawinan dimana tertuang dalam UU No 1 Tahun 1974 tentang Perkawinan dan saat ini terdapat juga Peraturan Pemerintah (PERMA) No 9 tahun 1975 tentang dilaksanakannya UU No. 1 Tahun 1974 mengenai Perkawinan. Didalam kehidupan berumah tangga 
pasti ada alasan-alasan yang akan dihadapi oleh pasangan suami-isteri dan dalam kondisi rumah tangga tersebut tidak dapat menyelesaikan permasalahan tersebut dengan tenang pasti akan mengalami perselisihan dan pertengkaran dalam hal ini suami istri sudah tidak dapat lagi di damaikan lagi maka perceraian yang selalu menjadi pilihan kedua pihak. Dalam UU No 1 Tahun 1974 ada dua macam perceraian yaitu cerai gugat dan cerai talak. Cerai gugat adalah putusnya perkawianan dimana hal ini sang istri melayangkan gugatan ke pengadilan. Cerai talak adalah putusnya perkawinan dalam hal ini suami yang mengajukan gugatan ke pengadilan. Undang-Undang Nomor 48 Tahun 2009 Tentang Kekuasaan Kehakiman menyatakan tugas Majelis Hakim didalam area pengadilan yaitu membantu dan memberikan masukan untuk mengatasi segala permasalahan yang ada. Perceraian merupakan terputusnya status perkawinan antara kedua belah pihak di muka pengadilan dan dengan alasan yang cukup mendukung bahwa diantara suami istri tidak dapat hidup lagi bersama. Putusanya perkawinan tersebut dapat dilakukan dengan alasan-alasan yang kuat dengan hukum perkawinan yang berlaku saat ini di Indonesia.

Beberapa penelitian mengenai gugatan cerai telah banyak dilakukan oleh peneliti sebelumnya Mantili \& Lubis (2017); Wirawan, Budiartha, \& Ujianti (2020); Duesenberg, (1959); Kusmayanti \& Puteri (2020); Melayu (2013); Mirsultan (2020); Popa \& Andreescu, (2017). Dalam mengajukan tuntutan hak ke pengadilan, penggugat harus datang dan membuat gugatan ke pengadilan. Gugatan merupakan tuntutan hak yang diajukan oleh penggugat kepada tergugat melalui pengadilan. Gugatan dapat dilakukan secara lisan mampu secara tertulis. Terdapat dua masalah yang sering terjadi dilingkungan pengadilan terutama dilingkungan pengadilan negeri dan pengadilan agama, yaitu yang pertama permohonan dan kedua masalah gugatan. Suatu gugatan harus mempunyai kepentingan hukum yang cukup, tetapi tidak berarti gugatan yang mempunyai gugatan hukum yang cukup akan dikabulkan oleh Majelis Hakim di pengadilan. Hal ini masih bergantung pada pembuktian. Dalam pelaksanaan udang-undang perkawinan terdapat batasan-batasan alasan perceraian yang diperbolehkan dan dapat diterima dipengadilan hal ini sangat penting tujuannya yaitu agar gugatan yang diajukan dapat diterima dan dikabulkan oleh majelis hakim. Di Pengadilan Agama terdapat beberapa macam gugatan yang dapat dijatuhkan oleh majelis hakim kepada pihak yang berperkara yaitu gugatan ditolak, gugatan diterima, dan gugatan diperbaiki.

Jika dalam proses persidangan terdapat alasan-alasan yang dapat menyebabkan Majelis Hakim menemukan sebuah fakta-fakta hukum yang membuat gugatan tersebut gugur atau tidak dapat diterima. Terdapat beberapa alasan yang dapat menyebabkan gugatan tidak dapat diterima karena cacat formil seperti surat kuasa yang diajukan tidak sah, gugatan diajukan oleh pihak penggugat tidak memiliki kepentingaan hukum, gugatan errorin persona, gugatan di luar prematur, gugatan obscuur libel, gugatan diluar kompetensi, gugatan daluwarsa. Berdasarkan latar belakang diatas, maka penelitian baru ini bertujuan untuk mengetahui akibat hukum dan pertimbangan hukum terhadap gugatan tidak dapat diterima dalam perkara cerai gugat pada Putusan Nomor 0063/Pdt.G/2017/PA.Bdg.

\section{METODE PENELITIAN}

Penelitian ini menggunakan tipe penelitian hukum normative dengan menggunakan pendekatan kasus. Adapun bahan-bahan hukum terhadap penelitian ini bersumber dari:

a. Bahan hukum primer, yaitu UU No 1 Tahun 1974 mengenai Perkawinan dan Peraturan Pemerintah (PERMAN) No 9 Tahun 1975 mengenai Pelaksanaan UU No 1 Tahun 1974 mengenai Perkawinan.

b. Bahan hukum sekunder, yaitu berupa laporan penelitian, buku yang ada kaitannya dengan permasalah yang akan diteliti. Dalam penelitian ini juga menggunakan putusan nomor 0063/Pdt.G/2017/PA.Bdg di Pengadilan Agama Badung dengan meneliti langsung dilapangan.

c. Bahan hukum tersier, yaitu berupa kamus hukum, kamus umum, dan enisklopedia.

Teknik pengumpulan data dilakukan dengan cara studi kepustakaan yaitu semua data dibaca, dan dicatat. Setelah itu dianalisis dan dideskripsikan serta diberikan contoh yang nyata sesuai dengan permasalahan yang dikaji. 


\section{HASIL DAN PEMBAHASAN}

\section{Akibat Hukum terhadap Gugatan yang Tidak Dapat Diterima dalam Perkara Cerai Gugat pada} Putusan Nomor 0063/Pdt.G/2017/PA.Bdg

Gugatan yaitu suatu solusi agar dapat mendapatkan perlindungan Majelis Hakim untuk menuntut hak yang seharusnya di dapat pihak dalam memenuhi kewajiban. Menurut Sudikno Mertokusumo menyebutkan pengertian Gugatan adalah tuntutan hak dalam hal tindakan yang bertujuan memberikan perlindungan yang diberikan oleh pengadilan untuk mencegah perbuatan main hakim sendiri (eigenrichting). Dan menurut Zainal Asikin, gugatan adalah suatu tuntutan yang disampaikan kepada ketua pengadilan yang berwenang oleh seseorang mengenai suatu hal akibat adanya persengketaan dengan pihak lainnya yang kemudian mengharuskan hakim memeriksa tuntutan tersebut dengan menggunakan cara tertentu yang kemudian melahirkan putusan terhadap putusan tersebut.

Dalam pengadilan yang megacu pada perkara perdata memiliki 3 macam kekuatan Putusan Pengadilan yaitu sebagai berikut:

1. Kekuatan putusan pengadilan yang mengikat yaitu sebagai sarana dalam menyelesaikan permasalahan dipengadilan melalui menetapkan hak yang adalah hukumnya sendiri. Pihakpihak yang tidak dapat menyelesaikan permasalahannya tersebut dengan baik biasanya akan menyelesaikan perkaranya kepada pengadilan.

2. Kekuatan Putusan pengadilan didalam Pembuktian dimana yang terdapat dalam bentuk tertulis adalah akta otentik yang bisa digunakan sebagai alat bukti oleh kedua pihak yang berperkara dalam pengajuan banding, kasasi atau pelaksanaannya.

3. Kekuatan eksekutorial putusan pengadilan yaitu terdapat dalam putusan peradilan yang dapat menjadi bahan pertimbangan putusan tersebut dilaksanakan dengan cara pihak yang tidak melaksanakan putusan tersebut secara sukarela.

Dalam upaya banding di Pengadilan Tinggi dengan cara membatalkan dan memberikan putusan yang berbeda dengan putusan di Pengadilan Negeri, maka putusan Pengadilan Negeri tersebut belum memiliki kekuatan hukum tetap. Namun jika putusan Pengadilan Tinggi tersebut dibatalkan ditingkat kasasi oleh Mahkamah Agung, maka putusan Pengadilan Tinggi belum mempunyai kekuatan hukum tetap. Dan jika dari pihak lawan yang dikalahkan tersebut melakukan upaya Peninjauan Kembali, maka keputusan Mahkamah Agung tersebut belum dapat dilaksanakan karena belum ada kejelasan tentang dikabulkan atau tidak permohonan peninjauan kembali tersebut. Jika dalam upaya peninjauan kembali tersebut tidak dikabulkan maka keputusan baru dapat dilaksanakan setelah tenggang waktu 14 hari terhitung sejak keputusan tersebut dikabulkan.

Materi dan pokok perkara yang ada didalam gugatan yang diteliti ini tidak dipertimbangkan oleh hakim, karena putusan yang diajukan tersebut menyatakan gugatan tidak dapat diterima ini sangat berpengaruh atau bergantung pada pembuatan atau penyusunan dalam surat gugatan, jika didalam pembuatan surat gugatan tersebut tidak benar dan tidak teliti dari segi prosedur dan perumusannya, serta tidak dapat memenuhi syarat formil dan syarat materil yang ditentukan maka hakim akan dapat menyatakan gugatan tidak dapat diterima atau niet ontvankeliike verklaard.

Gugatan tidak dapat diterima (Niet Ontvankelijke Verklaard) merupakan putusan dimana dalam hal ini hakim mengatakan gugatan tersebut tidak dapat diterima, karena mengandung cacat formil. Putusan tidak dapat diterima yaitu putusan akhir yang bersifat negatif. Terdapat beberapa alasan yang merupakan suatu penyebab sebuah gugatan tidak dapat diterima karena catat formil yaitu Surat kuasa yang diajukan tidak sah, Gugatan diajukan oleh pihak yang tidak memiliki kepentingaan hukum, Gugatan prematur, Gugatan di luar kompetensi, Gugatan obscuur libel, Gugatan error in persona dan Gugatan Daluwarsa. Dalam perkara yang diteliti penyebab gugatan tidak dapat diterima dalam perkara tersebut merupakan Gugatan Obscuur Libel. Gugatan obscuur libel adalah putusan gugatan bersifat kabur juga bisa disebut dengan tidak jelas dan tidak pasti. adalah:

Gugatan Obscuur Libel memiliki faktor-faktor penyebab kekaburan dalam gugatan tersebut

1. Dalil gugatan tidak mempunyai dasar peristiwa dan dasar hukum yang jelas

Surat gugatan penggugat bisa dikatakan tidak jelas jika dalam isi gugatannya tidak mempunyai dasar peristiwa serta dasar hukum yang jelas dalam memperjelas dasar hukum perkara tersebut dalam mendorong putusan gugatan tersebut. 
2. Kekaburan objek sengketa sering terjadi mengenai tanah.

Biasanya kekaburan objek sengketa terjadi karena tidak disebutnya batas-batas objek sengketa dan luas tanah dengan yang dikuasi tergugat.

3. Terdapat kontradiksi antara posita dan petitum

Dalam gugatan yang diajukan posita dan petitum yang diajukan harus saling menguatkan dan tidak saling bertentangan. Maka yang dapat dituntut dalam petitum harus dapat menyelesaikan sengketa yang didalilkan dalam gugatan.

4. Petitum tidak rinci

Dasarnya hal yang diingikan penggugat tersebut rinci dan jelas. Jika petitum primair ada secara rinci maka bisa digabung dengan petitum subsidair dengan jelas atau berbentuk kompossitur. Pelanggaran karena petitum gugatan tidak rinci ini dapat mengakibatkan gugatan tersebut tidak jelas.

5. Nebis in idem yang subyek dan obyeknya sama

Nebis in idem adalah Gugatan yang diajukan penggugat sudah pernah mengajukan perkara dengan kasus yang sama serta putusan tersebut sudah mempunyai kekuatan hukum, sehingga gugatan tersebut tidak dapat diajukan kembali untuk kedua kalinya.

Gugatan tersebut tidak dapat ditindaklanjuti oleh Majelis Hakim untuk diperiksa pokok perkaranya dan diadili sehingga tidak ada objek gugatan di dalam putusan untuk dapat dieksekusi.

\section{Pertimbangan Hakim dalam Memutus Gugatan yang Tidak dapat Diterima dalam Perkara Cerai Gugat pada Putusan Nomor 0063/Pdt.G/2017/PA.Bdg}

Dalam Pasal 1 Ayat (1) UU Kekuasaan Kehakiman adalah kekuasaan negara yang dapat menyelenggarakan peradilan dalam menegakkan hukum dan keadilan sesuai dengan Pancasila. Dalam hukum perdata formil, tujuan dari suatu perkara perdata yaitu agar dijatuhinya putusan yang sesuai dengan keadilan, maka semua pihak penggugat ataupun terguggat berhak untuk mendapatkan pembelaan atau bantuan hukum. Hukum perdata formil atau hukum acara perdata yang mengatur tentang bagaimanakah cara pihak yang berperkara di pengadilan dan bagaimanakah cara pengadilan dapat bertindak untuk menyelesaikan perkara perdata. Putusan pengadilan adalah suatu putusan yang sangat dinantikan dan diinginkan oleh pihak yang berperkara untuk dapat menyelesaikan perkara mereka dengan baik. Dalam pembuat atau penyusunan surat gugatan, penggugat dituntut untuk membuat gugatan dengan posita (fundamentum petendi) dan petitum yang jelas agar tidak terjadi permasalahan kedepannya. Menurut Artono (2011), surat gugatan adalah surat yang diajukan oleh penggugat kepada ketua pengadilan yang memuat tentang tuntutan hak yang didalamnya terdapat sengketa dan sekaligus merupakan dasar landasan pemeriksaan perkara dan pembuktian kebenaran suatu hak. Karena gugatan yang diajukan tidak disusun secara benar dan tidak memenuhi syarat formil dan syarat materil dalam pembuat gugatan dapat mengakibatkan gugatan tidak dapat diterima.

Putusan perkara yang diteliti ini adalah mengenai gugatan perceraian, dimana Penggugat didalamnya mendalilkan bahwa antara kedua pihak terakhir melakukan hubungan suami isteri dalam masa persidangannya sebanyak satu kali pada hari Senin Tanggal 10 April 2017 sekitar pukul 11 siang di warung tempat usaha bersama. Sejak terjadinya hubungan suami istri antara penggugat dan tergugat tersebut tergugat sampai sekarang belum haid dan diakui secara benar oleh pihak penggugat dan terguggat. Bahwa berdasarkan uraian dan fakta-fakta hukum diatas, jelas dan nyata bahwa Penggugat mengajukan gugatan yang dapat menghapus dalil gugatannya tersebut. Gugatan tersebut tidak dapat diterima karena faktor obscuur libel dimana dalil gugatan yang diajukan penggugat kepada Majelis Hakim tidak sesuai dengan kenyataan yang ada atau bisa disebut tidak rinci dan penggugat telah lalai, tidak cermat dan tidak teliti dalam menyusun Posita dan Petitumnya yang secara jelas membuat alasanalasan dan dasar-dasar hukum dalam gugatannya kabur dan tidak dapat diterima. Dimana dalam masa persidangannya antara kedua pihak suami isteri sempat melaksanakan hubungan suami isteri dan diakui secara benar oleh kedua belah pihak. Karena inilah Majelis Hakim berpendapat bahwa yang dilakukan oleh kedua belah pihak tersebut dapat menghapus dalil gugatan penggugat, maka gugatan tersebut gugur karena tidak berdasarkan hukum. Oleh karena alasan diatas gugatan penggugat dinyatakan tidak dapat diterima (Niet Ontvankelijk Verklaard). 


\section{SIMPULAN DAN SARAN \\ Simpulan}

Berdasarkan uraian pembahasan di atas maka disimpulkan bahwa putusan dengan amar Gugatan Tidak Dapat Diterima (Niet Ontvankelijke Verklaard) dalam kasus perceraian gugat di Pengadilan Agama Badung diawali dengan dimulainya dari pengajuan gugatan ke pengadilan, pemeriksaan di persidangan selanjutnya dilanjutkan dengan pembuktian dan terakhir yaitu kesimpulan sampai dengan penjatuhan putusan. Putusan dengan amar gugatan tidak dapat diterima merupakan putusan akhir yang bersifat negatif karena mengandung cacat formil. Alasan yang dapat menyebabkan gugatan tidak dapat diterima karena cacat formil yaitu Surat kuasa tidak sah, Gugatan diajukan oleh pihak yang tidak memiliki kepentingan hukum, Gugatan error in person, Gugatan prematur, Gugatan Obscuur Libel, Gugatan diluar kompetensi dan Gugatan Daluwarsa. Majelis Hakim dapat menyatakan gugatan tidak dapat diterima ini sangat bergantung dari awal pembuatan atau penyusunan surat gugatan, jika dalil gugatan yang dibuat oleh penggugat tersebut tidak memenuhi syarat formil dan materil yang telah berlaku saat ini menurut Undang-Undang, maka Majelis Hakim dapat menjatuhkan amar putusan gugatan tidak dapat diterima (Niet Ontvankelijke Verkklaard).

Kemudian, majelis Hakim dalam menjatuhkan putusan sudah mempelajari dan mempertimbangkan alasan-alasan yang diberikan di depan persidangan dengan mendengarkan pengakuan langsung dari kedua belah pihak dan dapat menyatakan putusan dengan amar Gugatan Tidak Dapat Diterima. Pertimbangan yang digunakan Majelis Hakim telah sesuai dengan ketentuan hukum acara perdata yang berlaku saat ini. Majelis hakim menjatuhkan putusan gugatan tidak dapat diterima karena surat gugatannya tersebut gugur karena tidak berdasarkan hukum. Gugatan yang diajukam tersebut tidak jelas atau kabur karena tidak memiliki dasar gugatan yang jelas. Karena alasan inilah Majelis Hakim dapat mempertimbangan dalam menyatakan putusan gugatan tidak dapat diterima tersebut yang dimana putusan tersebut bersisat negatif.

\section{Saran}

Melalui penelitian ini disarankan dalam mengajukan gugatan ke Pengadilan Agama pihak penggugat hendaknya lebih teliti dalam penyusunan dan pembuatan surat gugatan tersebut agar tidak mengandung cacat formil. Selain itu, diharapkan pembentukan aturan mengenai kewenangan hakim untuk dapat menghentikan pemeriksaan perkara perdata di pengadilan agama apabila majelis hakim telah menyatakan bahwa surat gugatan dari pihak Penggugat mengandung cacat formil untuk lebih menjamin penegakan dari Pasal 2 Ayat (4) UU Kekuasaan Kehakiman yang merupakan ketegasan dari asas peradilan yang cepat, sederhana dan dengan biaya ringan.

\section{DAFTAR PUSTAKA}

Artono, M. (2011). Praktek Perkara Perdata pada Pengadilan Agama. Yogyakarta: Pustaka Pelajar.

Duesenberg, R. w. (1959). Jurisdiction of Civil Court. OHIO State Law Journal, 20, 508-548.

Kusmayanti, H., \& Puteri, S. A. (2020). Dispute Settlement Practices through the Religious Court's Mobile Court (Sidang Keliling). FIAT JUSTISIA:Jurnal Ilmu Hukum, 14(3), 287.

Mantili, R., \& Lubis, S. A. (2017). Pertimbangan Hakim Pengadilan Negeri Terhadap Gugatan Perceraian yang Tidak Dapat Diterima (Niet Ontvankelijke Verklaard) dalam Praktik. ADHAPER: Jurnal Hukum Acara Perdata, 3(1).

Melayu, H. A. (2013). The Religious Court In Indonesia: A Preliminary Overview of Mahkamah Syar'iyah Aceh. Journal of Islamic Civilization in Southeast Asia, 1(1), 55-77.

Mirsultan, A. (2020). Divorce settlement among the Uyghurs during the Republican era in Xinjiang. Central Asian Survey, $0(0), 1-18$.

Popa, M., \& Andreescu, L. (2017). Legal provisions, courts, and the status of religious communities: a socio-legal analysis of inter-religious relations in Romania. Religion, State and Society, 45(3-4), 297-316.

Wirawan, I. P. W., Budiartha, I. N. P., \& Ujianti, N. M. P. (2020). Putusan Pengadilan Agama Badung Nomor 0166/Pdt.G/2017/Pa.Bdg tentang Cerai Gugat karena Salah Satu Pihak Berbeda Agama. Jurnal Preferensi Hukum, 1(2), 133-138.

Kitab Undang-Undang Hukum Acara Perdata.

Undang-Undang Nomor 1 Tahun 1974 tentang Perkawinan.

Peraturan Pemerintah Nomor 9 tahun 1975 Tentang Pelaksanaan Undang-Undang Nomor. 1 Tahun 1974. 